\title{
Some Tendencies of Modern Receiverships
}

W

HEN on April 20, 1915, the Chicago, Rock Island \& Pacific Railway Company was placed in the hands of receivers, the chairman of its board of directors issued to the press the following statement:

"A receivership at the present time is merely to obtain the protection of the court that the company's physical condition and equipment may be improved, its temporary loans continued and an opportunity be given for working out a comprehensive and permanent plan for financing to preserve for the shareholders the valuable equity which it is believed there is in the property." 1

This article proposes to deal with the kind of receivership thus pictured-a receivership which is apparently so advantageous for the shareholders of the corporation involved. For if stockholders, by securing the appointment of a receiver, can obtain for their corporation protection from its creditors and ability to raise new money for inprovements, a most desirable feature of corporate organization has been discovered.

Questions involving the powers of receivers and the results of receiverships are particularly important today. The general public is interested because there are or were in the hands of receivers during August, 1915, railroads operating 34,I96 miles of track and with securities aggregating \$2,042,384,890 par value. Managers of corporations are concerned because it has become the simplest of matters for a company to have a receiver appoimted ovèr its assets by the federal court.

The ease with which receivers may be appointed was well instanced in the case of the Chicago, Rock Island \& Pacific Railway. This road needed large amounts of money to be expended on it, it paid no dividends and it had certain notes coming due. It was, however, like many other low grade non-dividend-paying railroads

1 For full statement see The Commercial \& Financial Chronicle of New York, vol. 100, p. 1436. 
in this country. Suddenly, on April 20, I9I5, the American Steel Foundries, a New Jersey corporation, the owner of a claim totalling $\$ 15,818$, filed a bill in the United States District Court for the Northern District of Illinois, in which it prayed for the appointment of a receiver for the railroad. ${ }^{2}$ The company itself entered an answer, consenting to the appointment of receivers over its property. On the same day President H. U. Mudge and Hon. Jacob M. Dickinson were appointed receivers.

The method described of appointment of receivers through a bill filed by a simple contract creditor, joined in by the railroad itself, has been well established by the courts during the last eight years. In the matter of Reisenberg (Metropolitan Street Railroad case), ${ }^{3}$ the procedure was recognized by the United States Supreme Court. The New York City Railway Company was, in September, 1907, operating a system of surface street railroads in New York City. The Metropolitan Street Railway was interested, either as owner or lessee, in some eighteen railroads, all of which it had leased to the New York City Railway Company. On Septeunber 24, 1907, a bill was filed in the United States Circuit Court for the Southern District of New York by the Pennsylvania Steel Company, a citizen of Pennsylvania, and the Degnon Contracting Company, a citizen of New Jersey, in which the complainants alleged an indebtedness due from the railroad to them of over $\$ 4 x, 000$ and prayed for the appointment of a receiver over the property of the New York City Railway. The bill set out, among other matters, the insolvency of the railway, its mortgages, its many creditors and the grave danger of a dissipation of the assets of the company. An answer was at once put in by the New York City Railway Company, which admitted all the allegations of the bill and joined in the prayer of the bill that the court should take possession, by receiver, of the system of railroads operated by the defendant. Upon

2 For circumstances of receivership see Interstate Commerce Commission, In re Financial Transactions, History \& Operation of the Chicago, Rock Island \& Pacific Ry. Co. (1915), No. 6834. How unexpected was the receivership generally is shown by the fact that on April 19, 1915, the stock of the railway company sold at $363 / 4$. Upon the announcement of the receivership shares changed hands at $21 \%$.

3 (1907), 208 U. S. 90, 52 L. Ed. 403, 28 Sup. Ct. Rep. 219. 
this bill and answer an application was made to the circuit judge for the appointment of receivers, and receivers were duly appointed. In October, I907, the court granted an order making the Metropolitan Street Railway Company a party defendant and extending the receivership to it.

This procedure at once fixed the receivership proceedings in the United States Court and made the time elapsing between the filing of the bill and the appointment of the receivers very short. To the objection of collusion in the appointment of the receivers, Lacombe, C. J., said, in rendering the opinion of the lower court:

"There was no collusion apparent in any legal sense. It is of course manifest that complainants and defendants were entirely in accord, and arranged together that the suit should be brought to the federal court, and that the averments of the bill should be adinitted by the answer. But there was no colorable assignment of some clain to a citizen of another state, nor any misrepresentation or distortion of facts to mislead the court. On the contrary, examination of the books shows that the financial situation is precisely such as was averred in the complaimt." "

The decision was affirmed on appeal to the Supreme Court. From the standpoint of the corporation involved, such a method of securing a receivership is to be commended for several reasons. It is simple, as almost any large corporation can secure the co-operation of a non-resident creditor with a claim of $\$ 3,000$ or more. It is expeditious, for the bill praying for a receiver and the answer consenting can be filed within a few minutes of each other. It allows the corporation in financial difficulties to have the protection of the United States court.

Since the decision in the Metropolitan case corporations have not been slow in the use of creditors' bills for receivership purposes. Out of eleven receiverships of important railroads, with a total mileage of 22,107 miles, eight with 19,584 miles of track have had receivers secured by means of the creditor's bill. Any other procedure seems today to be an exception to the general rule.

The commencement of receiverships being so easily managed, the real question facing corporations is, what can be done after receivers are appointed; may the physical condition and equipment of a financially distressed railroad be bettered and time secured in which bills can be paid? Improvements on a railroad in receivers' 
hands must be secured through the expenditure of cash. Contractors and material men will not give credit to a road which cannot meet its existing bills. On a receivership a large system generally defaults on at least one issue of mortgage bonds. The interest money saved by the default on such bonds becomes applicable to the property. But, while the interest thus saved often runs into the millions, yet in such poor condition are the properties of many roads seeking receiverships that frequently the interest saved does little toward rehabilitating them. The natural and usual method of securing money to build up a road in receivers' hands is by the issue of receivers' certificates.

Receivers' certificates were first issued in this country after the period of the Civil War. Their exact origin is difficult to ascertain. Mr. Justice Bradley, in Wallace v. Loomis, ${ }^{5}$ is authority for the statement that the power of the courts to authorize such obligations "is a part of that jurisdiction, always exercised by the court, by which it is its duty to protect and preserve the trust funds in its hands." ${ }^{\text {B }}$ And certain support for such securities is found in the principle that a mortgagee in possession will be allowed for repairs necessary for the maintenance of the property and for doing whatever is essential for the protection of the title of the mortgagor.?

The earliest emphatic declaration of the power of the court to authorize receivers' certificates was made in 1875 , by the Supreme Court of Alabama, in the case of Meyer i. Johnston. ${ }^{8}$ There the court did not attempt to justify their issue as the mere application of any established principle. In a vigorous opinion, it pointed out that railroads were different froin other properties coming under the jurisdiction of the court of chancery, and that railroad receiverships demanded the establishment of new rules of law. The following extract from the decision shows the reasoning of the court:

"It was not necessary that the question of the power of a court to authorize the issue of first lien certificates of indebtedness to enable a receiver to raise the money he might need, should be decided before the introduction of railroads. But these properties, with their appurtenances, vast in extent and value, yet very perishable if unused and neglected, existing as

5 (1905), 97 U. S. 146, 162.

B See Morison v. Morison (1885), 7 De G., McN. \& G. 214; Vermont \& Canada R. R. v. Vermont Central R. R. (1877), 50 Vt. $500,580$.

?Sandon v. Hooper (1843), 6 Beav. 246; 2 Jones, Mortgages, $\$ 1126$.

8 (1875), 53 Ala. 237, 348. 
the estates of private individuals associated into corporations, but essentially public works, in whose operations the public at large and the state are concerned, when drawn into litigation, must be dealt with by the courts according to the nature and circumstances of the subject. And anyone can understand that the best and cheapest mode of conserving a railroad, may be by operating trains thereon, and keeping it in repair for their use. To preserve its value, it must generally be contmued in operation, and be sold as a going concern. If it were not for the public quality belonging to them, for the injury that would be done to the interests of whole communities, that have become dependent on a railroad for accommodation in a thousand things, a chancellor might say to the parties most interested: unless you furnish means for the protection of this property, which does not itself afford an adequate income for the purpose, it may become a dilapidated and useless wreck. But the inconvenience and loss which this would inflict on the population of large districts, coupled with the benefit, to parties who perhaps are powerless to take care of themselves, of preventing the rapid diminution of value, and derangement and disorganization that would otherwise result, seem to require-not for the completion of an unfinished work, or the improvement, beyond what is necessary for its preservation, of an existing one-but to keep it up, to conserve it as a railroad property, if the court has been obliged to take possession of it, that the court should borrow money for that puprpose, if it can not otherwise do so in sufficiently large sums, by causing negotiable certificates of indebtedness constituting a first lien on the proceeds of the property, and redeemable when it is sold or disposed of by the court."

It is needless to say that such an advanced theory received severe criticism. "Alas for the day," wrote Hon. Alexander M. Clayton, in 1878 , with reference to such certificates and to the application of due process of law, "when the owners' right and title to property can be subjected to the discretion of any court, and when a constitutional provision can be made subject to the idea of an undefined necessity "' ' But the courts meanwhile had quickly seized upon this extension of their power and in 1878 , Mr. Justice Bradley, rendering the opinion in Wallace v. Loomis, ${ }^{10}$ declared:

"The power of a court of equity to authorize such receivers to raise money necessary for the preservation and management of the property, and make the same chargeable as a lien thereon for its repayment, cannot, at this day, be seriously disputed."

913 American Law Review, p. 41.

10 (1877), 97 U. S. 146, 162, 24 L. Ed. 895. 
The courts at once recognized the grave dangers of receivers' certificates to the holders of equities in properties under receivership. In Meyer v. Johnston, ${ }^{11}$ the court wrote:

"Rash or facile chancellors may be persuaded to issue more certificates than are necessary for the mere conservation of the property; and when out they must all be redeemed: else, the whole scheme of raising money in this manner fails and the court is brought into disrepute. All power may be abused."

Mr. Justice Bradley, in Wallace v. Loomis, supra, declared:

"It is undoubtedly a power to be exercised with great caution; and, if possible, with the consent of the parties interested in the fund."

And in Credit Company v. Arkansas Central Railroad Company, ${ }^{12}$ the court said:

"But it is a power to be sparingly exercised. It is liable to great abuse, and while it is usually resorted to under the pretext that it will enhance the security of the bondholders, it not infrequently results in taking from them the security they already have, and appropriating it to pay debts contracted by the court." 13

Almost immediately the courts began to limit the scope of the power to issue receivers' certificates. The emphasis which the Alabama court, in Meyer v. Johnston, supra, laid upon. the necessity of operation of railroads because of the public interest involved was very shortly supported by decisions of the United States Supreme Court. In Barton v. Barbour, ${ }^{14}$ the court said, in referring to the obligation of a railroad to operate:

"Besides, the cessation of business for a day would be a public injury. A railroad is authorized to be constructed inore for the public good to be subserved than for private gain. As a highway for public transportation it is a matter of public concern, and its construction and management belong primarily to the commonwealth, and are only put into private hands to subserve the public convenience and economy."

The public interest in safe and continued operation of railroads as a basis for receivers' certificates was not strictly in accord with the theory that they were merely for the protection of property in the hands of the court. This theory did, however, enable the courts to limit the authorization of such securities to the railroad receiverships. The courts hesitated, but by 1895 it had become established

\footnotetext{
11 (1875), 53 Ala. 237, 349.

12 (1882), 15 Fed. 46, 49.

13 See Hanna v. State Trust Co. (1895), 70 Fed. $2,7$.

14 (1881), 104 U. S. 126, 134, 26 L. Ed. 672.
} 
by the federal courts that while receivers' certificates might be issued to pay taxes on the property of a private corporation, they could not be issued for other purposes as against the wishes of lien holders whose liens would be thereby displaced. ${ }^{15}$

In I895, Caldwell, C. J., on an application for receivers' certificates with a lien on the property of a private corporation, wrote:

"If the junior creditors of an insolvent corporation, could do what has been attempted in this case, every private corporation operating a sawmill, gristmill, mine, factory, hotel, elevator, irrigating ditches, or carrying on any other business pursuit, would speedily seek the protection of a chancery court, and those courts would soon be conducting the business of all the insolvent private corporations in the country." ${ }^{18}$

But, while the theory of the public interest guarded investors more closely by confining the powers of chancellors where receiverships of private corporations were concerned, it theoretically at least gave the courts increased powers over insolvent railroads. The early decisions did little toward establishing any sharp limits for the issuance of receivers' certificates. In Wallace v. Loomis, ${ }^{17}$ speaking generally, the court held that such certificates may lawfully be authorized "to raise money necessary for the preservation and manageinent of the property." This statement standing alone might indicate that the property was inerely to be kept in the shape in which it was received. Unfortunately, the Supreme Court had committed itself to approval of certificates which were not issued for the mere preservation of the property. In Jerome v. McCarter ${ }^{18}$ that court approved receivers' certificates for the completion of a canal in aid of which the United States had made a large grant of land, cunditioned upon the completion of the canal within a fixed time. "Hence there was a necessity for making the order which the court made, a necessity attending the administration of the trust which the court had undertaken. The order was necessary alike for the lien creditors and for the mortgagors." ${ }^{19}$ And in

15 Hanna v. State Trust Co. (1895), 70 Fed. 2; Farmers' L. \& T. Co. v. Grape Creek Coal Co. (1892), 50 Fed. 481; Fidelity Ins. T. \& Safe Dep. Co. v. Roanoke Iron Co. (1885), 68 Fed. 623 .

As pointed out in note 31 , infra, some courts seem to be swinging back toward the allowance of receivers' certificates on the property of private corporations.

16 Hanna v. State Trust Co. (1895), 70 Fed. 2, 8.

17 (1877), 97 U. S. 146, 162, 24 L. Ed. 895 .

18 (1876), 94 U. S. 734, 24 L. Ed. 136.

10 Jerome v. McCarter (1876), 94 U. S. 734, 738, 24 L. Ed. 136. 
Miltenberger v. Logansport etc. Railway, ${ }^{20}$ the court upheld receivers' certificates, with a prior lien to that of a pre-existing mortgage, created for the purpose of obtaiming rolling stock, and for building six miles of road and a bridge, part of the main line of a road ninety-two miles long.

"Rights under our system of law and procedure do not rest in the discretionary authority of any officer, judicial or otherwise," declared Mr. Justice Field in In re Parker ;21 but it was not for the lower courts to draw strict limitations as to the issuance of receivers' certificates after the Supreme Court had rendered its decision in Miltenberger v. Logansport, supra. The natural result was that the courts, while recognizing the dangers of such securities, made no rules which carefully regulated their authorization. The principles where laid down were characterized chiefly by their vagueness. A recognized authority wrote in 1886 :

"No limit has been fixed as to the purposes for which receivers' certificates may be issued, other than that they shall be germane to the objects of the receivership, and necessary to the proper administration of the trust." 22

In r8gr; the Circuit Court of Appeals Act, by making appeals to that court final in diversity of citizenship cases, in effect fixed, as a part of the law of receiverships, the principles of the Supreme Court cases previously decided. ${ }^{23}$

The present limitations by which the courts regard themselves bound are best shown by a portion of the opinion rendered by the Circuit Court of Appeals for the Sixth Circuit in the Pere Marquette receivership case:

"A railroad company owes a duty, not only to its creditors and stockholders, but, by virtue of its franchise, to the public as well; and a court which has undertaken the administration of railroad affairs is charged with the duty of conserving and operating the property, so far as can practically be done, for the benefit of botli public and private interests. In the exercise of this duty of conservation and operation, it may, in a proper case, make such repairs, replacements, and bettęrments as are purely essential to such results, and may, in a proper case, make the certificates for such loans a lien even

20 (1882), 106 U. S. 286, 27 L: Ed. 117, 1 Sup. Ct. Rep. 140.

21 (1888), 131 U. S. 221, 225, 33 L. Ed. 123, 9 Sup. Ct. Rep. 708.

22 High on Receivers, 2d ed., par. 398. comment by J. I. High in preface to third edition of High on Receivers, republished in fourth edition at page $\mathbf{v}$. 
upon the corpus of the property, and, so far as necessary, prior to existing liens." 24

A few courts have hesitated about recognizing such extensive powers as being possessed in chancery. The power given the receivers in Miltenberger v. Logansport Railway, supra, was an almost insurmountable block to conservative theories. One federal court did distinguish the case on the ground that there the increased valuation of the property far exceeded the expenditure made. The court said:

"But the power to postpone existing liens created by the court for the purpose of completing an unfinished railroad has rarely been exercised, and ought not to be exerted unless it can be done without ultimate loss to the existing lien holders." ${ }^{25}$

The line of least resistance was merely to allow or forbid receivers' certificates for the particular items of expense set out in petitions for their issue. And the law remains today as it was stated to be in the Pere Marquette receivership case, supra.

The wide discretion of the court, acting under such a theory of the law can best be shown by the examination of a concrete case. Let us consider the case of a railroad which, to be in the very best of operating efficiency, should be kept in a ninety per cent condition. But as a matter of fact its condition is sixty-five per cent. Its cars are old, uncomfortable and unpainted, its roadbed is in bad shape, and the whole road is justly a subject of much abuse by its passengers and shippers. The road has a capitalization of $\$ 5,000$,oon common stock, $\$ 5,000,000$ preferred stock, and $\$ 10,000,000$ first mortgage, five per cent bonds. For a few years after the organization of the company, dividends were paid on the preferred stock. These dividends were utterly unjustifiable and were paid from moneys which should have been expended upon maintenance of the property. When these payments could not be saved by further skimping the maintenance account, the dividends ceased. By this time the proper expenditures on the property had to be cut in order to meet the interest due upon the bonds. For a few years the bonded interest was paid and then, unable to hold off its creditors any longer, the management puts the railroad into receivers' hands.

24 American Brake Shoe \& F. Co. v. Pere Marquette Ry (1913), 205 Fed. 14, 19.

25 Bibber-White Co. v. White River Valley Electric Ry. Co. (1902), 115 Fed. 786, 790. For a conservative view, see also Illinois Steel Co. v. Ramsey (1910), 176 Fed. 853, 865. 
Interest payments on the $\$ 10,000,000$ bond issue at once cease and an expenditure of $\$ 500,000$ per annum is thereby saved. The receiver finds that to put the road in a ninety per cent condition will require $\$ 5,000,000$ to be expended on the property. The expenditure on the railroad of the $\$ 500,000$ annual interest charge saved will, however, make the road into a very fair operating property within three years. The road will then be able to pay at least $\$ 350,000$ in interest or dividends and take care of all proper charges for maintenance and operation. The newspapers are, however, violent in their attacks on the road and its poor service.

Under the decisions referred to, the receiver can apply to the court and secure permission for the issue of $\$ 5,000,000$ five per cent receivers' certificates. At the time of the receivership the road was annually earning $\$ 250,000$, which might properly be paid out as bonded interest. We presume that the receiver issues the $\$ 5$,$\infty, \infty 00$ receivers' certificates. These certificates are a first lien upon the property and bear total interest charges of $\$ 250,000$. Now if the expenditure of the $\$ 5,000,000$ means a permanent increase of $\$ 250,000$ in annual net earnings, the bond holders will be in as good a position after as before the certificates were issued, except that their mortgage will be a second and not a first lien on the property. But if these certificates merely inean better stations, equipment, etc., and do not bring additional net earnings, the \$10,$\infty, 000$ bondholders will be ousted from any equity in any earnings whatever. Their bonds, on which two and one-half per cent was being earned, will have, after the issuance of the certificates, nothing earned on them.

Such a reduction in the equity in the earnings on the property generally means a complete loss to the bondholder. Heavier rails, better cars and magnificent bridges will do him no good unless they bring additional earnings. His bond will sell high or low according to the amount earned by the railroad and the number of times over the bond interest is being earned. And if no earnings whatever are applicable to them, his bonds will sell for little or nothing.

In expending the proceeds of receivers' certificates, the courts and their officers cannot look into the future and guarantee that certain expenditures will bring certain results. The wisest railroad executives in this country make occasional bad mistakes. And the ability to build up a non-paying into a paying property is a quality of only the very ablest inen. When therefore a receiver with a large cash fund easily secured through certificates issued, plunges 
into the building up of a railroad, he is undertaking one of the most difficult tasks in modern commercial life. And necessarily the probabilities are that he will not succeed-that money will be freely spent but that it will not bring the result. sought. Yet a court is doing no unusual thing in giving to a receiver an opportunity to try his fortune toward securing results through expending money thus raised. The court is merely acting within its powers and allowing certificates no more freely than do a great number of courts in this country. Manifestly new construction is not necessary to endanger the equity of the bondholders. A radical policy of improvement may be perfectly effective in reducing his security to a nominal value.

What then have been the results of the exercise of this remarkable power by the courts? Receiverships are the natural followers of panics. Since the doctrine of receivers' certificates was established, we have had in the United States three periods of severe industrial depression, which were preceded by financial crises. These crises occurred in 1873,1893 and 1907 . It cannot be said that the courts obtained unusual benefits for railroads by their early issues of receivers' certificates. Beach, in I891, wrote:

"Within the last twelve or fifteen years these certificates, to the amount of many millions of dollars, have been issued, and the courts are constantly authorizing the further issue of them, ostensibly for the preservation of the property and in the interest of the bondholders, but it is believed in a majority of cases in which they are issued, to the hindrance and delay of a prompt foreclosure, to the impairment of the bondholders' security, and to the scandal of the courts of equity." 26

Comparatively speaking, the issue of receivers' certifieates prior to I900 was not very large. The courts had not become accustomed to the certificates in the depression from $1873-1878$. And in the period froin $1893-1898$ the courts were not liberal in their issue. During the decade prior to 1907 , receiverships were unusual. It was a very prosperous time for this country. But since 1907 there have been few years in which business conditions have been good, and there have been several years in which industrial affairs have been very much depressed. Receiverships have been a natural consequence. Today receiverships give rise to problems very different from those presented twenty and thirty years ago. With the period of marked prosperity after I897, came the era of holding companies

28 Beach, Law of Receivers, § 379. 
and of great corporate consolidations. Small independent railroads went out of fashion; it becaine the day of huge systems of lines. Railroads bought great private industries, and great industries bought railroads. Companies were figuratively built one upon another, until some parent corporation, by leases or agreements, or by holding a majority of the voting securities of other corporations, which controlled still other corporations, dominated the entire structure. Street railroads followed the example set by the steam lines and corporations controlling city franchises were pyramided for financial reasons.

The same ten years prior to 1907 were characterized by a rapid development in the theories regarding the duties of the railroads toward the public. It was a part of the rapid decline in the individualistic beliefs held to so strongly in this country during the latter part of the nineteenth century. The doctrine of laissez faire found its few supporters rapidly dwindling in number. By roo7 a great majority of the courts, as well as the legislatures had firmly recognized the important responsibihties of transportation companies to the people at large.

This growth in the theory of the public interest in public utilities, coming at practically the same period as the consolidation in railroads, made the position of bondholders insecure. It would be very easy for a court, facing the many questions of these large receiverships, to allow the time of foreclosure to be postponed for years. And it would be equally natural for a court believing in the modern theory of public interest to allow receivers' certificates to issue on an unprecedented scale. This is exactly what happened.

The largest system which, since I907, has had receivers appointed, and the property sold under foreclosure, has been the Wabash Railroad Coinpany. Receivers over the property of this company were appointed on December I8, rgrr. By May I, I9I5, there had been issued receivers' certificates totalling $\$ 15,950,000$ and $\$ 1,545,000$ in receivers' equipment certificates. The issue of this amount of receivership obligations is explained by a statement, dated April 28, '1915, of the Joint Reorganization Committee of the security holders of the Wabash Railroad Company, submitting the plan of reorganization later adopted. In this statement it is said:

"In December, Igrx, the Wabash Railroad passed into the harids of receivers and in the following inonth proceedings were instituted to foreclose the First Refunding and Extension Mortgage under which default had occurred on January I, I9I2. 
Committees representing bonds and stock were organized, having for their object an independent and sound reorganization, and forthwith entered upon an investigation of the financial position of the Company and the physical condition and requirements of its properties. To this end, in co-operation with the receivers, exhaustive and comprehensive examinations of the property were made by competent experts.

The receivers and committees encountered serious problems presented by the deterioration of property and equipment, inadequacy of facilities and the absence of the commercial credit essential to the maintenance and extension of business. With the provision of resources through the issue of receivers' certificates, aided and guided by expert advice and with the cooperation of the committees, the receivers undertook an improvement and equipment plan which has carried the property to its present high state of actual and competitive efficiency. The receivers have already effected more than 80 per : $u$ nt of the expenditures recommended as desirable to be made through a series of years ending in 1917 , in order under normal business conditions, to realize an estimated initial advancement of the revenues of the property comprising about 2500 miles, to $\$ 15,000$ per mile, and to reduce its operating ratio to a maximum of 70 per cent, or gross earnings of $\$ 37,659,000$ and net earnings of $\$ 11,297,700 . "$

From the market standpoint, the position of the $\$ 40,600,000$ first refunding and extension bonds was not improved by the receivership. During I912 these bonds sold between $551 / 2$ and $723 / 8$. In September, 19I5, they touched $135 / 4{ }^{27}$

The Atlanta, Birmingham \& Atlantic Railroad owns 622 miles of track in Alabama and Georgia. On January 2, 1909, receivers were appointed over the property. The railroad has issued $\$ 14,-$ 443,000 bonds which, at the commencement of the receivership, constituted a first lien on more than half the trackage. Receivers' cer-

27 The re-organization plan can hardly be criticized upon the ground that it is not sufficiently. liberal to the bondholders. That the stockholders received no great benefit under it is shown by the fact that Wabash Railroad common stock sold in September, 1915, at ask $1 / 8$ and the preferred stock sold at ask $1 / 4$. The re-organization plan provided for the issue of $5 \%$ preferred $A$ stock with a large amount of common stock as a bonus, to raise money necessary for the cash requirements. To provide funds sufficient to meet the receivers' certificates under the plan, preferred A stock with dividend charges of $\$ 1$,369,000 annually was issued. Since the first refunding, bondholders received the principal and interest of their bonds in preferred $B$ stock. 'The ultimate result of the issue of receivers' certificates was that this permanent charge came in ahead of them. The current selling price is 40 for the preferred A stock on the New York curb. 
tificates to the amount of $\$ 4,994,000$, or at the rate of $\$ 8,030$ per mile were issued. An attempt was made in 1914 to sell the road on foreclosure but the bondholders bidding were not able to pay the enhanced price, which the receivers' certificates made necessary. Payment of the principal of the receivers' certificates has been long defaulted. The bonds referred to sold in January, I9Io, at bid 53, asked 57. They sold in July, 1915 , at bid $1 / 4$, asked $\mathrm{I}$.

A case involving a street railroad company is that of the Second Avenue Railroad in New York City. This corporation went into receivers' hands on November 12, 1908. Receivers' certificates to the amount of $\$ 3,140,000$, or at the rate of over $\$ 200,000$ per mile have been issued. The price of the First Consolidated Mortgage Bonds has fallen from bid 81, asked 82, in January, 1909, to bid 5, asked 15 , in July, 1915 .

Such free use of receivers' certificates has not been confined to the cases cited. To restrict the issue of these securities has been exceptional. A table of the certificates issued by all the leading roads going into the hands of receivers prior to July I, I9I4, and subsequent to January I, 1907, follows:

\begin{tabular}{|c|c|c|c|}
\hline NAME OF RAILROAD & $\begin{array}{l}\text { Date of } \\
\text { Appointing } \\
\text { Receivers. }\end{array}$ & $\begin{array}{c}\text { Receivers, } \\
\text { Certikcates } \\
\text { Outstanding. }\end{array}$ & $\begin{array}{l}\text { Receivers' } \\
\text { Certtifcates } \\
\text { Per Mile } \\
\text { of Road. }\end{array}$ \\
\hline $\begin{array}{l}\text { Pittsburg, Shawmut \& } \\
\text { Northern Railroad....Aug. I, }\end{array}$ & 1905 & $\$ 3,100,000$ & $\$ 10,922$ \\
\hline $\begin{array}{l}\text { Wabash Pittsburg Ter- } \\
\text { minal Railway }\end{array}$ & 1908 & $2,395,880$ & 619 \\
\hline Wheeling \& Lake Erie R.R. June 8, & 190 & $7,258,850$ & 14,419 \\
\hline $\begin{array}{l}\text { Pere Marquette Railroad.April 5, } \\
\text { St. Louis \& San Fran- }\end{array}$ & I912 & $4,830,000$ & 2,362 \\
\hline $\begin{array}{l}\text { cisco -..... May 27, } \\
\text { Chicago \& Eastern Illi- }\end{array}$ & IgI & $3,000,000$ & 570 \\
\hline $\begin{array}{l}\text { nois Railroad ............... } \\
\text { Metropolitan Street Rail- }\end{array}$ & IgI & $6,000,000$ & 066 \\
\hline $\begin{array}{l}\text { way } \\
\text { Third Avenue Railway.........Jan. } 6 \text {, }\end{array}$ & $\begin{array}{l}1907 \\
1908\end{array}$ & $\begin{array}{l}6,500,000 \\
2,500,000\end{array}$ & $\begin{array}{l}37,963 \\
73,529\end{array}$ \\
\hline
\end{tabular}

The perilous position of a railroad bondholder is easy to see. A conservative banker may truthfully advise the purchaser of a bond in a public utility corporation: "Your bond is secured by a valid first mortgage on real property. The security seems sufficient and

28 All the properties mentioned except that of the Metropolitan Street Railway Company and of the Third Avenue Railway Company were during September, 1915, still in the hands of receivers. 
no management, however dangeruus, can take it from you without payment of your bond. But if a receiver is appointed over the property of the corporation, receivers' certificates will probably be issued. Your mortgage will then become a second lien. You will be fortunate indeed if your security is slightly impaired and it may result in its entire dissipation." 29

There can be no evasion of responsibility by the courts wnen the security of the bondholders is seriously impaired through receivers' certificates. That the receiver and the stockholders will urge the necessity of such certificates may be taken for granted. As Judge Caldwell said:

"When a receiver is appointed under such a bill, he usually makes haste, as the receiver did in this case, to assure the court that if he only had some capital to start on, he could greatly benefit the estate by carrying on the business that bankrupted the corporation. In this case, the company being insolvent, and its property mortgaged for more than it was worth, there was no way of raising money to set the receiver up in business, except by the court giving its obligations, in the form of receivers' certificates, and making them a paramount lien on all the property of the corporation, by displacing the appellants' prior liens thereon. As commonly happens in cases of this character, the insolvent corporation, and the junior mortgagee united in urging the court to arm its receiver with the desired powers. They ran no risk in so doing. The corporation was insolvent, and a foreclosure of the prior mortgage would leave the junior mortgagee without any security; so that it had nothing to lose and everything to gain, in experiments to enhance the value of the inortgaged property, so long as the cost of those experiments was made a prior lien thereon." 30

29 The effect upon the value of bonds of private corporations, if courts are allowed to issue receivers' certificates freely, has been well recognized.

"If it were once settled that a chancery court could carry on a business of such insolvent corporations at the risk and expense of those holding the first or prior liens on the-property, such liens would have little or no value." Hanna v. State Trust Co. (1895), 70 Fed. 2, 8.

"But if it ever be declared that the lien of the bondholders of an industrial corporation may be displaced, without consent by a court order, the result would be that such corporations could not obtain loans from responsible institutions or investors, hence disaster and a destructive blow at legitimate business enterprises." In re J. B. \& J. M. Cornell Co. (1912), 201 Fed. 381, 388. See In re Maplecroft Mills (1914), 218 Fed. 569, 665 .

If this be true as to industrial corporations, it is equally true as to public service companies. The value of any bonds is based upon the continued earning power of the security, not upon the nature of the security, except in so far as it indicates future earning power.

30 Hanna v. State Trust Co. (1895), 70 Fed. 2, 8.

In a recent case, Smith D. J. said: "Where stockholders have made mortgages whose prior liens they themselves must respect, they are prone to appeal to the extraordinary power of a court of equity for 
But it may be urged that the courts, by obtaining the consent of the committees usually formed to represent the bondholders, can place upon them the responsibility for the consequences of the issuance of receivers' certificates. Any study of such committees shows that this cannot be done. A so-called bondholders' protective committee is, in nearly all cases, merely a self-appointed body which, beginning with a sinall nucleus of securities, sends broadcast appeals that with it all bonds be deposited. It is absolutely necessary that one committee have control of practically the entire issue of bonds, so that it can bid in the property mortgaged on foreclosure sale and deliver the bonds held as payinent. The small bondholder knows that the formation of two rival bondholders' committees will simply delay reorganization and cause expense. He further knows that he must deposit his bonds ultimately with the committee or he will be excluded from participation in the reorganization scheme and receive only his cash pro rata of the foreclosure sale price. Since the committee formed will in all probability be the only bidder, the property will be sold for a fraction of its value, and the bondholder staying out of the reorganization scheme will receive little. The small bondholder, therefore, has practically no choice. He must deposit with the bondholders' committee. But it is clear that the court cannot fairly look to the bondholders' protective committee for authority to take steps which may divest the bondholders of their lien. Furthermore, these bondholders' committees rarely have control of all the bonds. Some few security holders do not deposit, or deposit their bonds very late with the committee. Such committees therefore cannot pretend to represent all the bonds. It is impossible to escape the conclusion: the property is in the hands of the court; the receiver is an officer of the court; and for his actions, good or ill, the court must assume the responsibility.

The statement quoted of the chairman of the board of directors of the Rock Island System may have seemed unwarranted. Certainly his picture of the advantages of a receivership to stockholders is extraordinary. Is it not, however, the natural conclusion to be drawn from the development of the law under which receivers are appointed by means of simple creditors' bills and then are given a very free hand in raising inoney through receivers' certificates? ? $^{31}$

their benefit to displace and destroy the liens they themselves have created, so as to raise additional funds for the operation of a business in whose speculative result the stockholders are alone interested." In re Maplecroft. Mills (1914), 218 Fed. 659, 666.

a1 What has been said in this article regarding railroads applies 
That this condition of the law will long continue is unbelievable. The courts, in taking possession of corporate property at the instance of stockholders, and improving it at the risk of the bondholders, are simply inviting attack. If they succeed in making their improvements increase the earnings of the railroads, they will gain small thanks from the security holders. When the equities of the bondholders are dissipated through receivers' certificates, the courts are placed in a position where explanation is almost impossible. Meanwhile, confidence in the value of American railroad bonds must steadily diminish when first mortgages are so contingent upon the will of the courts. It would be idle to predict the future attitude of the courts toward receivers' certificates. Clearly the purchaser of bonds of the railroads may hope with reason for the promulgation of rules which limit the power of the lower courts in receivership cases.

Certain changes in the law suggest themselves as among those which the courts might reasonably make:

(I.) A fixed rule that only under extraordinary circumstances will money for new construction or improvements be permitted to be raised; the court to do little more than attempt to keep the property in the condition in which it is when receivers are appointed.

(2.) The very shortest possible receiverships; foreclosure proceedings to be carried through with expedition; and receiverships for more than one year to be rare. This is necessitated by a very limited use of receivers' certificates. If receiverships are prolonged, it often becomes necessary to raise large amounts of money for improvements. ${ }^{32}$ The public no longer to expect the rehabilitation of

equally to other public service companies operating gas, electric light, heat and power, water works, traction and subway properties. There has, moreover, been a tendency toward authorizing receivers' certificates for the improvement of property owned by private corporations. Thus within the last two years receivers' certificates were issued in the International Steam Pump Company, International Typesetting Machine Company, and Ogara Coal Company receiverships. See Atlantic Trust Co. v. Chapman (1907), 208 U. S. 360, 371, 52 L. Ed. 551, 28 Sup. Ct. Rep. 324.

${ }^{32}$ In the case referred to, of the Fort Smith Railroad, the proceedings to foreclose were speeded to a decree rendered to meet the exigencies of the case, which the Supreme Court approved, and said "was a much more desirable plan' than to issue receivers' certificates. Shaw v. Railroad Co., 100 U. S. 612." Credit Co. v. Arkansas Cent. R. R. Co. (1882), 15 Fed. 46,50 . 
insolvent properties by the court. If improvements are a necessity, the legislatures and commissions can compel them to be made after the receivers are discharged. Entire responsibility for the raising of new money through securities, with prior liens or otherwise, will then be placed upon the holders of bonds secured by mortgages. No more delay of the discharge of receivers until money market conditions make reorganization easy. The reorganized company which takes the property over on foreclosure may be temporarily financed through new short term obligations, corresponding to receivers' certificates. This is no reason why the court should retain control of the property.

(3.) A lapse of some days between the filing of a bill praying for a receiver and the appointment of the receiver. Hearing by the court of all parties interested as creditors or stockholders of a corporation, who wish to appear and make known their views upon the question of the necessity for a receivership. The refusal to allow a receivership which is evidently made for the sole benefit of the stockholders of the corporation.

The promulgation of any such primciples would be a long step toward the protection of security holders. But for the courts to drift along in their present course means their frequent assumption of responsibilities which they cannot successfully undertake, and it means also that they are willing to countenance the undermining of what has been so invaluable in the growth of this country-American railroad credit.

San Francisco, California.

Thomas A. Thacher. 